\title{
RHODONITE-PYROXMANGITE FROM TANATZ AlP, SWITZERLAND
}

Franca Caucia, Luigi Marinoni, Maria Pia Riccardi, Omar Bartoli, and Maurizio Scacchetti

The chemical, physical, and gemological properties of attractive rhodonite-rich rocks from Tanatz Alp (Switzerland) were investigated using classical gemological methods, petrographic observation, and analytical techniques such as X-ray powder diffraction, Raman spectroscopy, and scanning electron microscopy. The color of the samples varied from pale pink to purplish pink; they were opaque and contained braunite, rhodochrosite, and spessartine. The gem-quality samples have an attractive color and are compact with no fractures. Tanatz Alp rhodonites are characterized by the presence of other minerals such as kutnohorite, spessartine, ankerite, rhodochrosite, khristovite-(Ce), pyroxmangite, and chlorite. The presence of the polymorph pyroxmangite was also confirmed by micro-Raman analyses. The samples had a chemical composition of $\mathrm{MnO}(45.97-48.64 \mathrm{wt} \%$ ) and $\mathrm{SiO}_{2}(46.70-47.92$ wt. \%), with very low amounts of $\mathrm{MgO}(0.64-1.65$ wt. \%) and $\mathrm{CaO}(<5$ wt. \%). Rhodonites from Tanatz Alp have some economic importance because of their use in jewelry and ornamental objects.

$\mathrm{R}$ hodonite is the Mn-rich member of the pyroxenoid group; it is triclinic with a structure made up of silicate chains parallel to the c-axis, in turn composed of a repeating sequence of five tetrahedral units. The chains alternate with $\mathrm{M}$ octahedral sites, designated M1 though M5, where divalent cations reside (Deer et al., 1997, and references therein). The ideal chemical formula is $\mathrm{MnSiO}_{3}$. Rhodonite of this composition has been synthesized but has never been found in nature, where $\mathrm{Ca}, \mathrm{Mg}$, and $\mathrm{Fe}^{2+}$ replace $\mathrm{Mn}$ (Ito, 1972).

Rhodonite was first discovered in 1790 in the Ural Mountains near Sidelnikovo. The mineral was named in 1819 by the German naturalist Christoph Friedrich Jasche. The name is derived from the Greek rhodo, which means "rose," because of its characteristic pink color (figure 1). The Hermitage Museum in Saint Petersburg preserves many precious and decorative objects made with rhodonite that belonged to the Russian aristocracy, especially the czars. Even today, Russian children exchange rhodonite eggs for Easter as a gesture of friendship. In the United States there are important rhodonite mines in New Jersey and in Massachusetts, which declared it the official

See end of article for About the Authors and Acknowledgments.

Gems \& Gemology, Vol. 56, No. 1, pp. 110-123,

http://dx.doi.org/10.5741/GEMS.56.1.110

(C) 2020 Gemological Institute of America state gem in 1979. Rhodonite is collected as a lapidary material and ornamental stone and is used to make cabochons, beads, small sculptures, tumbled stones, and other objects. High-quality crystals of

\section{In Brief}

- Rhodonite from Tanatz Alp in Switzerland is associated with kutnohorite, spessartine, ankerite, and rhodochrosite.

- Classical gemological methods, petrographic observation, and analytical techniques demonstrated the presence of the two polymorphs of $\mathrm{MnSiO}_{3}$ : rhodonite and pyroxmangite.

- Fashioned rhodonites from Tanatz Alp display an attractive pale pink purplish pink color.

this mineral can be very expensive. Rhodonite is generally found in massive translucent to opaque aggregates, and the best-quality gems are transparent. The crystals have perfect cleavage in two directions and low hardness (5.5-6 Mohs), making it one of the most difficult gemstones to cut. For this reason, faceted rhodonites are typically sold as collectible gems rather than for jewelry use.

Rhodonite is very similar to its polymorph, pyroxmangite, and to rhodochrosite $\left(\mathrm{MnCO}_{3}\right)$. Pyroxman- 


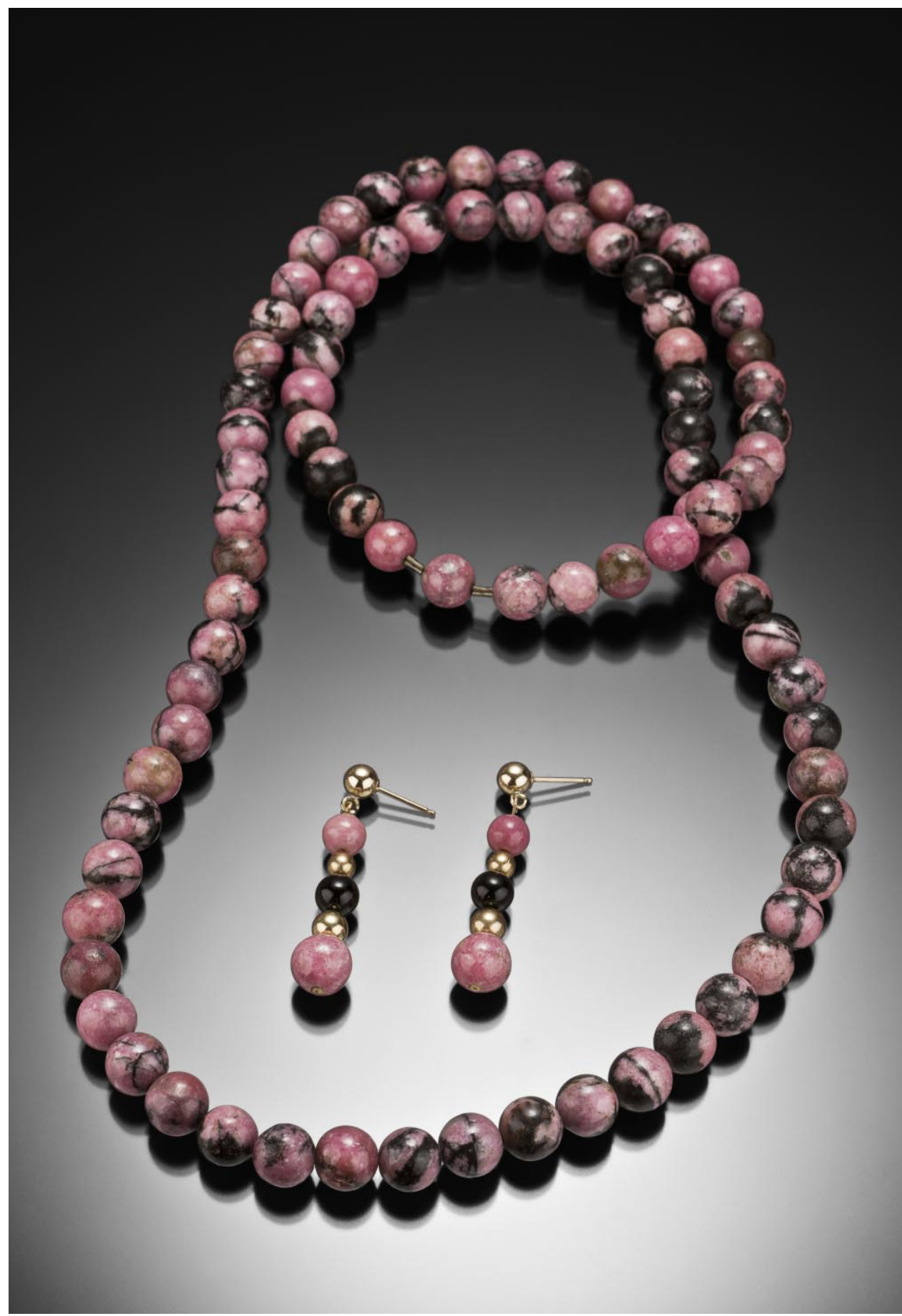

Figure 1. Rhodonite bead necklace and earrings. Photo by Emily Lane; courtesy of Dona Dirlam.

gite has a structure very similar to that of rhodonite, with a repeating sequence of seven tetrahedral units; the distinction from rhodonite therefore requires more accurate investigations with techniques such as X-ray powder diffraction (XRPD) and electron microprobe. Rhodochrosite differs in that it frequently shows white streaks of calcite and is reactive to hot acids, whereas rhodonite is resistant to acids and usually associated with manganese oxides.

Rhodonite and pyroxmangite contain small amounts of $\mathrm{Ca}, \mathrm{Mg}$, and $\mathrm{Fe}^{2+}$ substituting for $\mathrm{Mn}^{2+}$; the $P$-T compositional stability limits have been investigated by many authors, but there are still uncertainties (Ito, 1972; Peters et al., 1973; Ohashi et al., 
1975; Maresch and Mottana, 1976; Brown et al., 1980; Akaogy and Navrotsky, 1985; Abrecht, 1988; Takahashi and Hariya, 1995; Zanazzi et al., 2008; Diella et al., 2014, and references therein). The two minerals can generally be distinguished on the basis of their chemical composition, as rhodonite contains a higher amount of $\mathrm{Ca}$ (more than $0.05 \mathrm{wt} . \%$ ) than pyroxmangite. Rhodonite and pyroxmangite often occur together as a bladed intergrowth, in various types of ore deposits and Mn-rich lithologies (Ohashi et al., 1975; Jefferson et al., 1980; Pinckney and Burnham, 1988; Millsteed et al., 2005; Michailidis and Sofianska, 2010).

Deposits of rhodonite are found all over the world. The most important are those at Broken Hill in New South Wales, Australia, where the best single-crystal gems are found (Millsteed et al., 2005; Millsteed, 2006); Franklin, New Jersey, in the United States (Nelson and Griffen, 2005); many areas of the Ural Mountains (Bukanov, 2006; Brusnitsyn, 2010); British Columbia, Canada (Simandl et al., 2001); Huánuco, Peru (Wilson,1989); Minas Gerais, Brazil (Quinn, 2004; Leverett et al., 2008); Pajnsberg, Sweden (Lee, 1958); and several localities in Japan (Ohashi et al., 1975). A variety of rhodonite containing high levels of zinc (up to $10 \mathrm{wt} . \% \mathrm{ZnO}$ ), called fowlerite, was found at Franklin, New Jersey (Nelson and Griffen, 2005).

In the Italian Alps, rhodonite has been found in the Praborna mine near San Marcel in Valle d'Aosta (Mottana, 1986), Feglierec near Alagna Valsesia in Piedmont (Peters et al., 1978), Monte Forno in Malenco Valley, Scerscen in Lombardy (Diella et al., 2014), and Monte Civillina in Veneto (Schiavinato, 1953). Rhodonite is also found in the Apennines chain, in the mines of Gambatesa and Molinello in Graveglia Valley in Liguria (Marchesini and Pagano, 2001), Alpe Ravinella in Strona Valley (Bertolani, 1967), Scortico in the Apuan Alps (Di Sabatino, 1967; Mancini, 1997), and Campiglia Marittima in Tuscany (Capitani et al., 2003). Italian rhodonites are translucent or opaque and microcrystalline with a pale to deep pink color; only those from Monte Forno in Val Malenco (Diella et al., 2014) and Scortico (Apuan Alps) can be truly considered gem-quality since they are transparent enough to be faceted.

The manganese deposits in the Rhetic Alps of Switzerland that contain rhodonite, such as Falotta and Alpe Parsettens in the Oberhalbstein or Fianel and Starlera in Val Ferrera, have been widely investigated (Trommsdorff et al., 1970; Peters et al., 1973, 1978; Wenk and Maurizio, 1978; Brugger and Giere,
1999), but those in the Tanatz Alp (figure 2) are less well known. This work investigates the chemical, physical, and gemological properties of rhodonite from Tanatz Alp.

\section{DESCRIPTION OF THE DEPOSIT}

Tanatz Alp is located about 2.5 kilometers south of the village of Splügen in the Swiss canton of Grisons. The geological setting is similar to that of the more famous Val Ferrera. Tanatz Alp lies between the crystalline basement and the sedimentary cover of the Tambo nappe in the so-called Spluga zone; a short distance to the east is the nappe of Suretta. Both nappes belong to the Pennidic domain and are formed by rocks of the crystalline basement, metamorphosed during the Alpine orogeny, and by overlying shallowbasin sedimentary sequences, which were subsequently metamorphosed into $\mathrm{Mn}$ - and Fe-rich schists and quartzites (Biggioggero and Montrasio, 1990; figure 2). The first description of the minerals from Tanatz Alps was by Kenngott (1866), who reported the discovery of rhodonite in Mount Splügen.

At the beginning of the twentieth century, interest in manganese minerals increased considerably, and this Swiss resort became an economically important source (Grenouillet, 1920). Rhodonite in Tanatz Alp occurs in large isolated boulders between half a meter and a meter long (figure 3), distributed along an extension of about 100 meters on the slope to the west of the switchbacks ascending the pass at an elevation of 1,720 m. Between 1918 and 1920, excavations were carried out to identify the original outcrop of this mineral, but without success. Since 1970, stonecutters and artisans have rediscovered an appreciation for the manganese minerals of Tanatz Alp, which are multi-colored, hard, and free of cavities and cracks. Many collectors around the world also became interested in this area, where several very rare and attractive minerals can be found (gasparite, khristovite, franklinfilite, tiragalloite, and manganberzeliite; Roth and Meisser, 2011).

The source region of these rhodonite-bearing boulders has never been identified, and its mineralogical composition is still the subject of investigation. It is believed that the manganese-rich deposits formed during the Tertiary, under zeolite and greenschists facies metamorphic conditions (Roth and Meisser, 2011). It was assumed that the mineralization took place in the Triassic carbonate sediments, similar to the famous deposits of Fianel and Starlera in nearby Val Ferrera (Brugger and Giere, 1999), but 


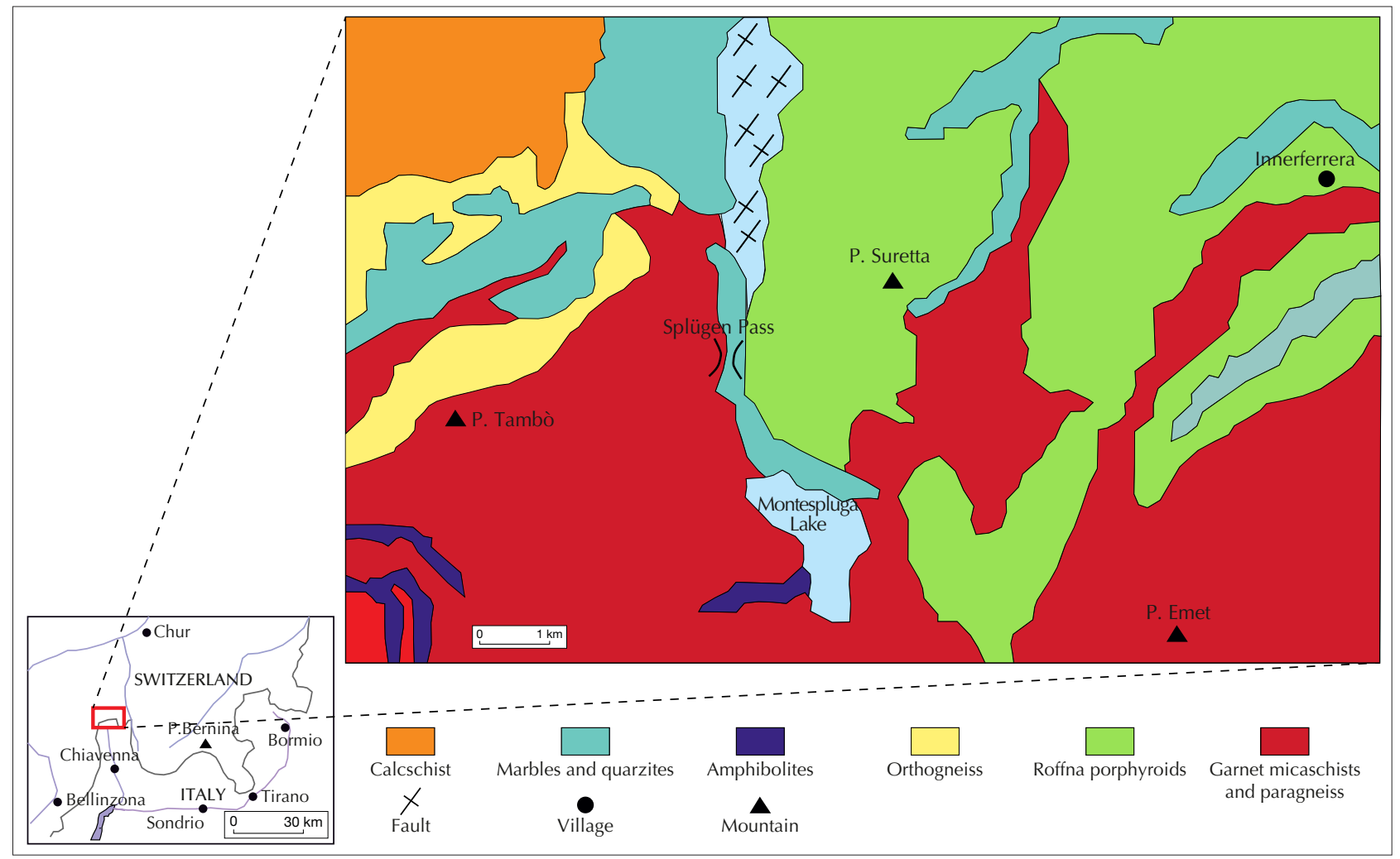

Figure 2. Geological map of the Tanatz Alp area in Switzerland. Modified from Bedogné et al. (1995).

the original outcrop is likely located in the crystalline intercalation of the Splügen area, which is tectonically very complex (figure 2 ).
The mineralogy of the rhodonite-bearing rocks from Tanatz Alp shows similarities with that of deposits from Scerscen in Val Malenco, located about

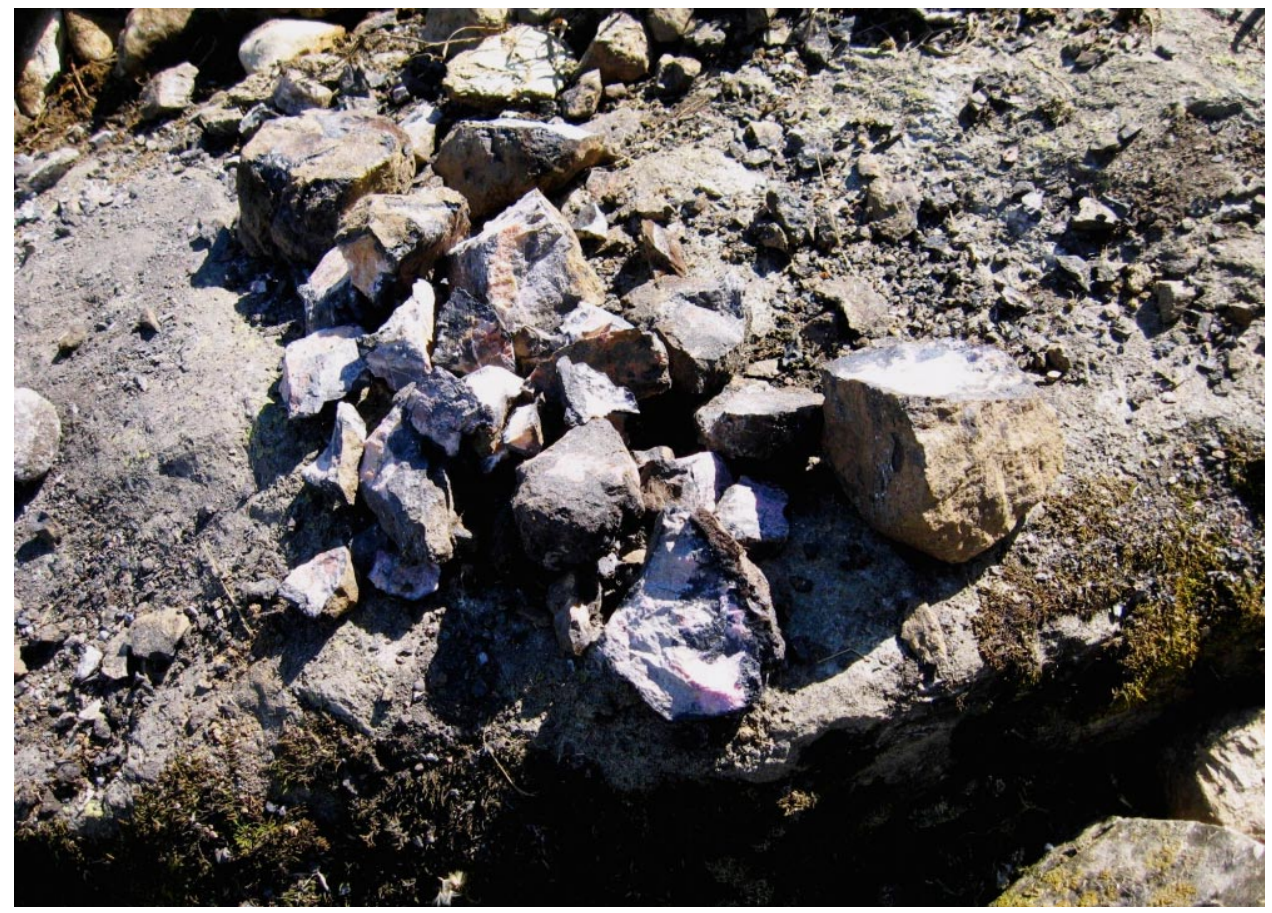

Figure 3. A loose assortment of blocks containing the rhodonite mineralizations investigated in this work. The largest is about $1 \mathrm{~m}$ long, while the overlying blocks are about 20-25 cm long. Photo by F. Vanini. 


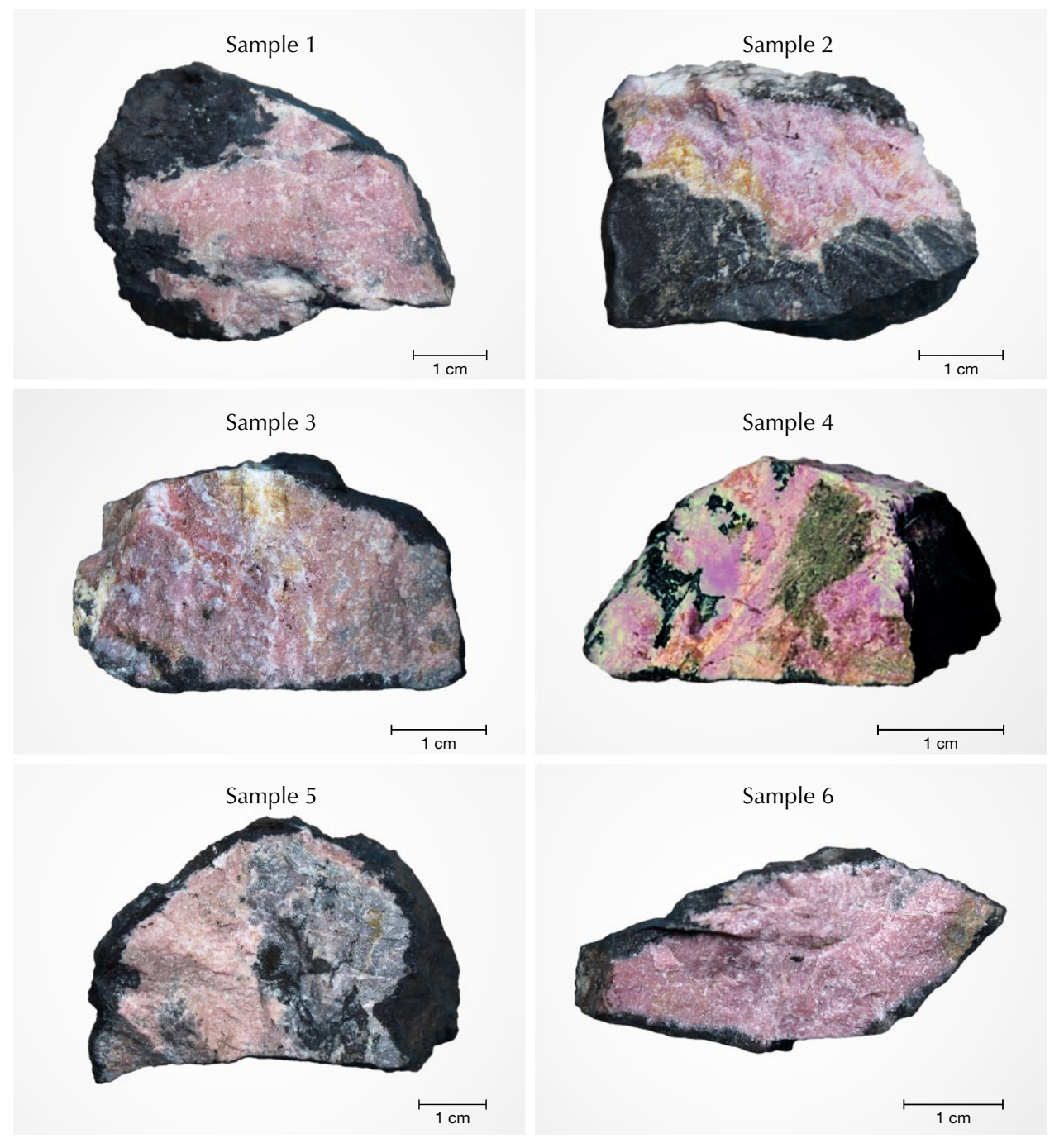

Figure 4. Rough samples of rhodonite from Tanatz Alp investigated in this work (samples 1-6). Photos by Maurizio Scacchetti.
40 km away (Bedogné et al., 1993, 1995; Diella et al., 2014). On the surface, the manganese boulders are black. The alteration layer varies from a few millimeters to one centimeter and is composed of rancieite. Rhodonite is present in small, needle-like crystals with a characteristic and very pleasing pink color, often in contact with spessartine.

\section{MATERIALS AND METHODS}

Analyses were carried out on six samples of rock containing rhodonite (figure 4), collected from Maurizio Scacchetti in the summer of 2017 along the main road leading to the Splügen Pass. The samples were in centimeter sizes, with very uneven color due to the presence of different minerals. The rhodonite was present in these samples as fine needle-like crystals. There were also millimeter-sized and rounded orange crystals of spessartine and light pink rhodochrosite and brown or blackish portions made up of braunite and manganese oxides such as rancieite. All the samples were compact.

Standard gemological analyses were carried out on seven fashioned stones (figure 5), cut from the rough samples in figure 4 , to describe the optical properties, specific gravity, and ultraviolet fluorescence. Density was measured using a Presidium PCS100 Sensible hydrostatic balance, and the color was evaluated with an RGB (red, green, blue) color table. Refractive index was measured by the distant vision method using a Kruss refractometer (1.45-1.80 range) and a contact liquid with an RI of 1.80. Ultraviolet fluorescence was investigated with a shortwave $(254 \mathrm{~nm})$ and long-wave (365 nm) UV lamp.

$\mathrm{X}$-ray powder analyses to determine the mineralogical composition were carried out using a Philips PW1800 powder diffractometer, with $\mathrm{CuK} \alpha$ radiation 

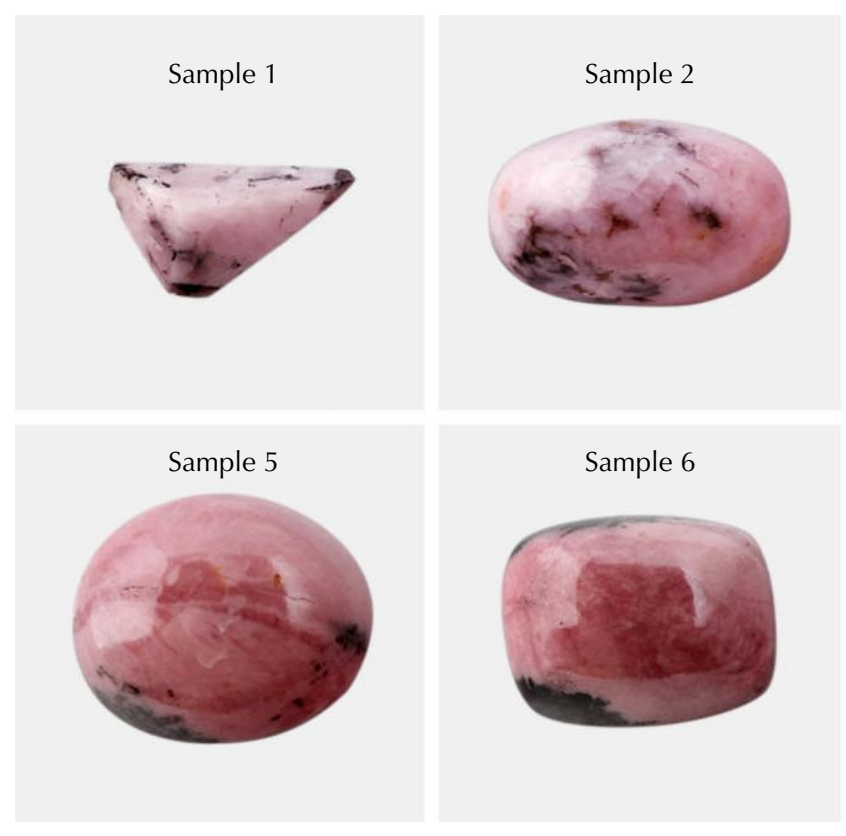

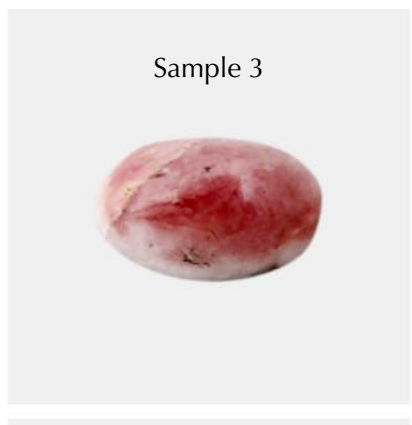

Sample 7

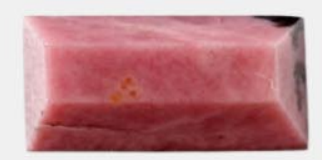

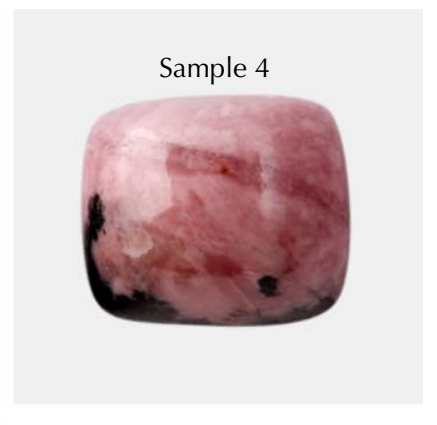

Figure 5. Cut gems of rhodonite from Tanatz Alp, ranging from 0.43 to $12.70 \mathrm{ct}$. Photos by Federica Montanelli. $(\lambda=1.5418 \AA)$ and a scan speed of $1 \%$ min, in the $2-$ $65^{\circ} 2 \theta$ range. The samples for the analyses (about $3 \mathrm{~g}$ ) were previously ground in an agate mortar and reduced to a very fine powder (about 5 microns). We ground the rough samples shown in figure 4 . The material was selected based on the pink color before the grinding. Unfortunately, many phases of rhodonitebearing rock show a similar color (spessartine orangepink, rhodochrosite reddish pink, and kutnohorite pale pink). Therefore, in the Results section rhodonite represents less than $50 \%$ of all samples except sample 2. Qualitative and semi-quantitative evaluation was performed with $\mathrm{X}^{\prime}$ Pert HighScore software, which is designed to obtain all phase information from loose and pressed powders and other polycrystalline samples (Markvardsen et al., 2008; Degen et al., 2014).

Major element analysis ( $\mathrm{Si}, \mathrm{Mn}, \mathrm{Ca}, \mathrm{Mg}, \mathrm{Fe}, \mathrm{Zn}$, $\mathrm{Ti}$, and $\mathrm{Al}$ ) was carried out on select crystals from all the rhodonite samples with an electron microscope, model TESCAN series Mira XMU, coupled with an EDAX system with energy dispersion and no internal standard (analytical error of about 3\%). The accelerating voltage was $20 \mathrm{KV}$, while the analysis area was $100 \times 100 \mu^{2}$. The accuracy of the analyses is related to the calibration of the detector and the maintaining of standard conditions during the work.

Micro-Raman scattering measurements were conducted with a Horiba Jobin Yvon Explora Plus single monochromator spectrometer (grating of 2400 groove $/ \mathrm{mm}$ ) equipped with an Olympus BX41 microscope. Raman spectra were recorded with $532 \mathrm{~nm}$ excitation. The spectrometer was calibrated to the silicon Raman peak at $520.5 \mathrm{~cm}^{-1}$. The spectral resolution was $\sim 2 \mathrm{~cm}^{-1}$, and the instrumental accuracy in determining the peak positions was approximately $0.56 \mathrm{~cm}^{-1}$. Raman spectra were collected in the spectral range $100-1300 \mathrm{~cm}^{-1}$ for 5 seconds averaging over 40 scans accumulated.

\section{RESULTS}

Microscopic Observations. Figure 6A shows a macroscopic section of a rhodonite sample (no. 2) that contains a pink and a dark part. Thin-section investigation revealed that the pink portion (figure 6B) consists of an intimate association of rhodonite (or pyroxmangite) and kutnohorite (see chemical analyses in table 5). Here, the size of rhodonite/pyroxmangite crystals ranges from tens of micrometers to a few millimeters. Conversely, the dark part is composed mainly of spessartine and Mn oxides (figure 6C).

Gemological and Physical Properties. Seven cabochons and faceted stones were cut with various shapes (figure 5) from the six rough samples; table 1 presents the gemological data.

The cabochons and faceted stones had a massive and opaque aspect with an intense and variable pink color (pink, pale violet red, and Indian red according to the RGB color table). The rhodonites were strongly inhomogeneous due to the presence of various associated minerals in spots that were dark to black and yellow-orange. The measured specific gravity ranged from 3.40 to 3.63, in agreement with data for other alpine rhodonites (Deer et al., 1997; Diella et al., 

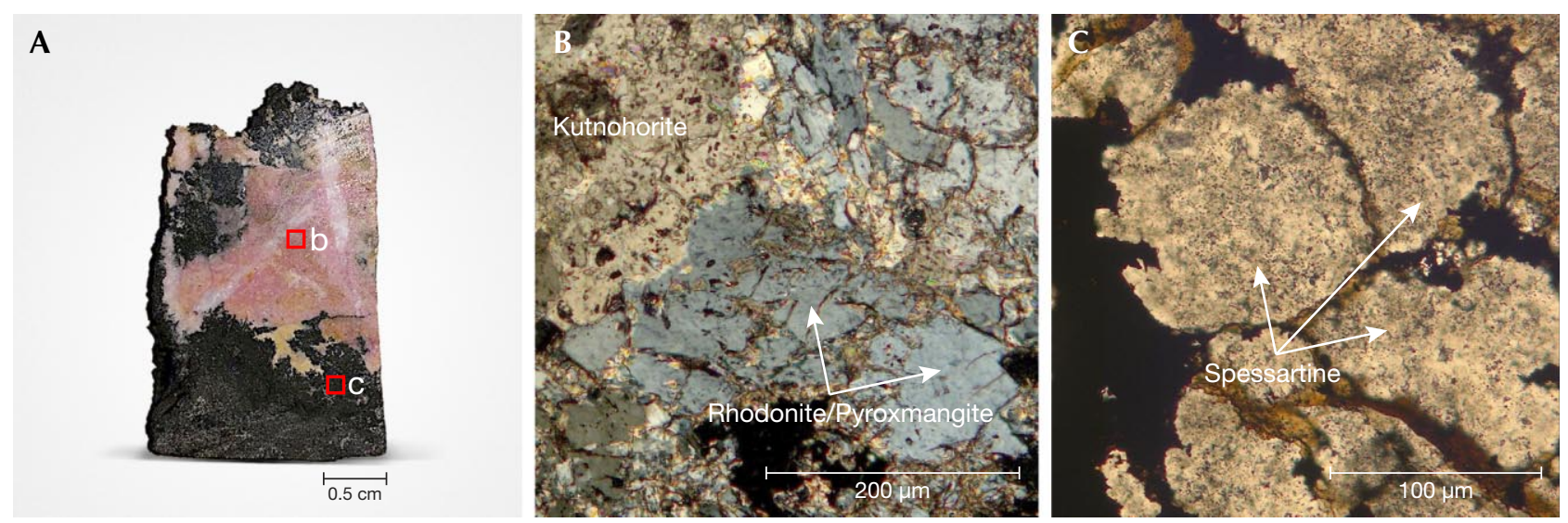

Figure 6. A: In this slice obtained from rough sample 2, red squares indicate the points of microscopic observation shown in figures $4 B$ and $4 C . B$ : A crossed polarizer image reveals the coexistence of kutnohorite and rhodonitel pyroxmangite. C: A plane-polarized light image shows the presence of Mn-rich garnet. Photos by Omar Bartoli.

2014). The refractive indices measured with the distant vision method ranged from approximately 1.72 to 1.74 (in agreement with Deer et al., 1997; Diella et al., 2014). The absorption spectra were characterized by a broad band at $550 \mathrm{~nm}$, a strong narrow line at $500 \mathrm{~nm}$, and a diffuse weak band at $450 \mathrm{~nm}$. All the samples were inert to short-wave $(254 \mathrm{~nm})$ and longwave (365 nm) UV.

XRPD. Figure 7 shows the X-ray patterns of some investigated samples, while the mineralogical composition is reported in table 2 . The samples showed a variable occurrence of rhodonite-pyroxmangite, but distinguishing the two phases is quite difficult be- cause of the two polymorphs' overlapping peaks at $26.6,29.1,30.2,34.4$, and $36.5^{\circ} 2 \theta$. The rhodonite was identified by the characteristic peaks at $21.5,25.0$, $27.4,28.5,30.5,32.2$, and $35.4^{\circ} 2 \theta$, while the sole pyroxmangite presented diffraction effects at 25.5, 28.1, $29.8,31.3,40.8$, and $44.3^{\circ} 2 \theta$.

The samples showed variable amounts of rhodonite-pyroxmangite (22-66\%) and kutnohorite (8-62\%); samples 1, 4, and 6 also contained ankerite. Other detected minerals were spessartine, rhodochrosite, calcite, braunite, chlorite, and traces of quartz. In samples 1, 2, 4, and 6, the X'Pert software also suggested traces of the rare mineral khristovite, identified by the peaks at $25.3,30.6,32.8$, and $34^{\circ} 2 \theta$.

TABLE 1. Gemological data of the rhodonite cabochons and faceted stones investigated.

\begin{tabular}{|c|c|c|c|c|c|c|}
\hline Sample & $\begin{array}{c}\text { Color } \\
\text { (RGB color table) }\end{array}$ & $\begin{array}{l}\text { Dimensions } \\
\quad(\mathrm{mm})\end{array}$ & Cut & $\begin{array}{l}\text { Weight } \\
\text { (ct) }\end{array}$ & $\begin{array}{l}\text { Specific } \\
\text { gravity }\end{array}$ & $\mathrm{RI}^{\mathrm{a}}$ \\
\hline 1 & Pink; black spots & $7 \times 4 \times 3$ & Triangular cabochon & 0.43 & 3.40 & 1.72 \\
\hline 2 & Pink/pink1; black spots & $12 \times 7 \times 6$ & Oval cabochon & 5.30 & 3.41 & 1.73 \\
\hline 3 & $\begin{array}{l}\text { Pale violet/"Indian red } \\
2^{\prime \prime} ; \text { pink veins }\end{array}$ & $7 \times 5 \times 5$ & Oval cabochon & 1.08 & 3.42 & 1.73 \\
\hline 4 & $\begin{array}{l}\text { Pale violet/"Indian red } \\
2 \text { " veins }\end{array}$ & $10 \times 12 \times 6$ & Rectangular cabochon & 12.01 & 3.60 & 1.74 \\
\hline 5 & $\begin{array}{l}\text { Pale violet/"Indian red } \\
2 \text { " veins; black spots }\end{array}$ & $12 \times 13 \times 5$ & Oval cabochon & 12.51 & 3.56 & 1.74 \\
\hline 6 & $\begin{array}{l}\text { Pale violet/“Indian red } \\
2 \text { "; black spots }\end{array}$ & $13 \times 10 \times 7$ & Rectangular cabochon & 12.70 & 3.58 & 1.74 \\
\hline 7 & $\begin{array}{l}\text { "Indian red"; black } \\
\text { spots }\end{array}$ & $12 \times 6 \times 4$ & Rectangular emerald-cut & 3.70 & 3.63 & 1.74 \\
\hline
\end{tabular}




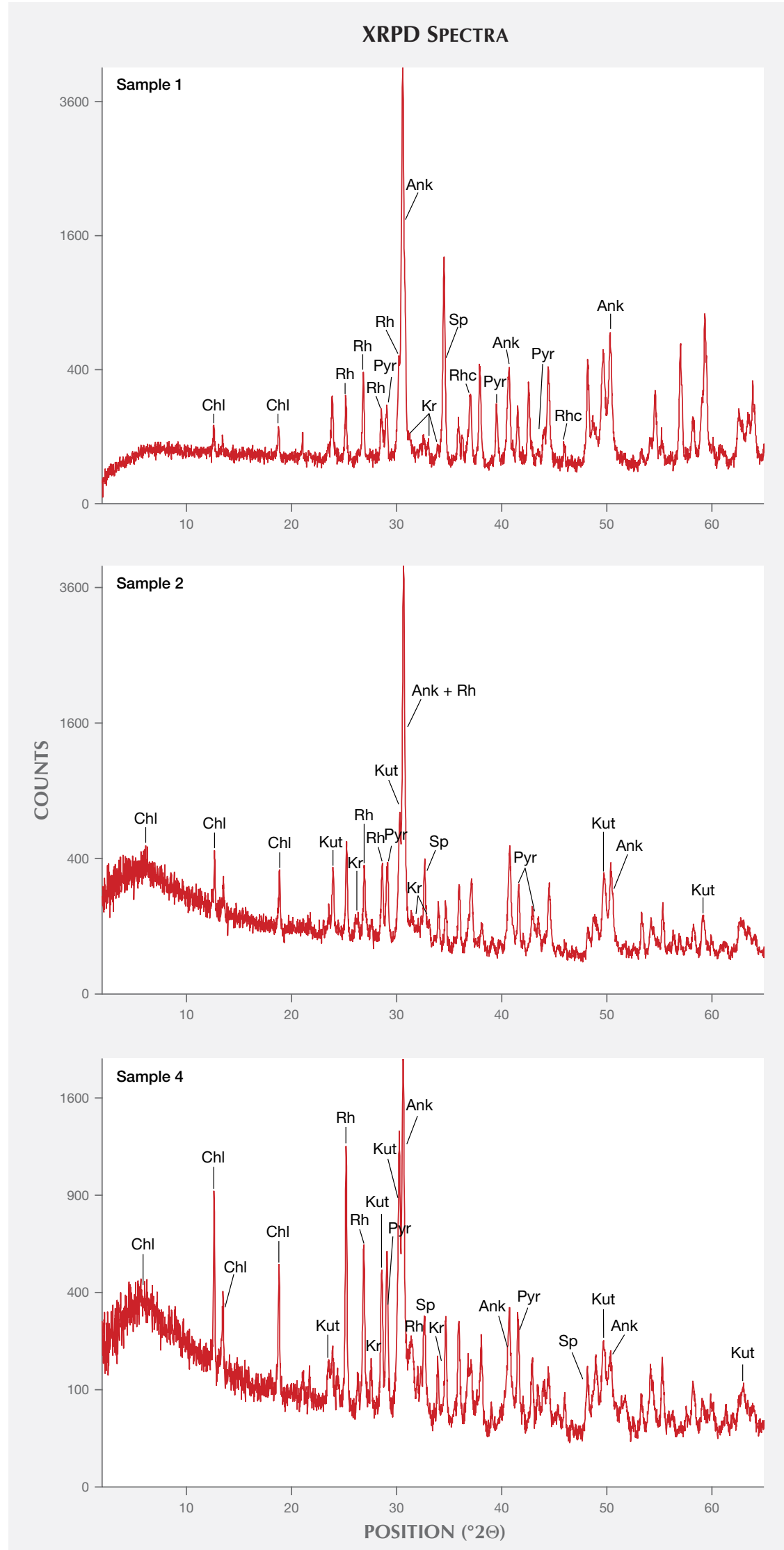

Figure 7. XRPD patterns of the rhodonite samples 1, 2, and 4 from figure 4 . The most important minerals are reported, close to their diagnostic peaks. Ank = ankerite; Pyr = pyroxmangite; $R h=$ rhodonite; Kut = kutnohorite; $S p=$ spessartine; $R$ hc = rhodochrosite; $\mathrm{Chl}=$ chlorite . 


\begin{tabular}{|c|c|}
\hline Sample no. & Mineral assemblages (wt.\%) \\
\hline 1 & $\begin{array}{l}\text { Ankerite }(60 \%) \text {, rhodonite-pyroxmangite }(20 \%) \text {, rhodochrosite }(20 \%) \text {, khristovite (traces), } \\
\text { chlorite (traces) }\end{array}$ \\
\hline 2 & $\begin{array}{l}\text { Rhodonite-pyroxmangite }(65 \%) \text {, kutnohorite }(25 \%) \text {, spessartine }(5 \%) \text {, chlorite }(5 \%) \text {, } \\
\text { quartz (traces), khristovite (traces) }\end{array}$ \\
\hline 3 & Kutnohorite $(60 \%)$, rhodonite-pyroxmangite $(30 \%)$, calcite $(10 \%)$ \\
\hline 4 & $\begin{array}{l}\text { Rhodonite-pyroxmangite }(35 \%) \text {, spessartine }(30 \%) \text {, ankerite }(15 \%) \text {, kutnohorite }(10 \%) \text {, } \\
\text { chlorite }(10 \%) \text {, khristovite (traces) }\end{array}$ \\
\hline 5 & $\begin{array}{l}\text { Rhodonite-pyroxmangite }(45 \%) \text {, braunite }(20 \%) \text {, ankerite }(10 \%) \text {, kutnohorite }(10 \%) \text {, } \\
\text { spessartine }(10 \%) \text {, quartz }(5 \%)\end{array}$ \\
\hline 6 & $\begin{array}{l}\text { Rhodonite-pyroxmangite }(40 \%) \text {, spessartine }(30 \%) \text {, kutnohorite }(20 \%) \text {, ankerite }(10 \%) \text {, } \\
\text { khristovite (traces) }\end{array}$ \\
\hline
\end{tabular}

Mineral Chemistry. SEM analyses performed on selected crystals of rhodonite-pyroxmangite are shown in table 3 (error of analyses about $3 \%$ ). Table 4 reports the chemical composition of rhodonites from the Alps and other worldwide occurrences reported in the literature, for comparison. In our samples the most abundant oxides were $\mathrm{MnO}$ (46-48.64 wt.\%) and $\mathrm{SiO}_{2}$ (46.70-47.92 wt.\%), with very low amounts of $\mathrm{MgO}$ (0.64-1.65 wt.\%) and $\mathrm{CaO}$ (<5 wt. \%).

Figure 8 and table 5 provide the backscattered electron images and corresponding analyses of the association of rhodonite (points 3,4, and 5) with CaMn-carbonate kutnohorite $\left(\mathrm{CaMn}^{2+}\left(\mathrm{CO}_{3}\right)_{2}\right.$; points 1 and 2). We also observed the presence of Mn oxides and spessartine as accessory phases. The rhodonite in the samples appeared to be composed of microcrystals, and the chemical composition was not homogeneous. Similar to what was reported for rhodonites from Val Malenco (Diella et al., 2014), we observed that the Si content was almost stoichiomet- ric $(\mathrm{Si}=1.00-1.01 \mathrm{apfu})$ while that of $\mathrm{Mn}$ deviated (0.82-0.88 apfu) from the idealized formula (1.00 apfu), due to the occurrence of other cations such as $\mathrm{Ca}$ and $\mathrm{Mg}$ in the M-sites.

The $\mathrm{Ca}$ and $\mathrm{Mn}$ contents in our samples were similar to those reported for other samples from Val Scerscen, Val Sesia Val d'Ayas, and Val Malenco (Peters et al., 1978; Mottana, 1986; Diella et al., 2014; see table 4).

$\mathrm{CaO}$ contents also showed large variability in the same areas investigated by energy-dispersive spectroscopy (EDS) analyses. It varied from $0.97 \%$ to $3.90 \%$ in samples 1 and 2 , from $0.99 \%$ to $3.97 \%$ in sample 4 , and from $1.02 \%$ to $4.64 \%$ in sample 5 ; see table 3. The values of Ca vs. Mn are plotted in figure 9 with the different fields for rhodonite and pyroxmangite (see also Diella et al., 2014).

Fe was absent in our samples, as in rhodonite from other localities in the Alps such as Praborna and Val Sesia and from Japan; see table 4. In the

TABLE 3. Chemical composition (wt.\%) of the rhodonite/pyroxmangite samples investigated, obtained through SEM analyses.

\begin{tabular}{|c|c|c|c|c|c|c|c|c|c|c|c|c|}
\hline Oxides & $1 / 1^{\mathrm{a}}$ & $1 / 2$ & $2 / 1$ & $2 / 2$ & $3 / 1$ & $3 / 2$ & $4 / 1$ & $4 / 2$ & $5 / 1$ & $5 / 2$ & $6 / 1$ & $6 / 2$ \\
\hline $\mathrm{SiO}_{2}$ & 46.91 & 46.62 & 47.02 & 46.63 & 46.70 & 47.03 & 47.43 & 46.92 & 47.66 & 46.53 & 47.62 & 47.54 \\
\hline $\mathrm{MgO}$ & 0.67 & 1.44 & 0.70 & 1.45 & 0.64 & 0.68 & 0.57 & 1.65 & 0.75 & 1.46 & 0.84 & 0.85 \\
\hline $\mathrm{MnO}$ & 48.52 & 50.75 & 48.42 & 50.95 & 48.64 & 48.49 & 48.33 & 50.44 & 46.95 & 50.98 & 46.85 & 47.41 \\
\hline $\mathrm{CaO}$ & 3.90 & 0.98 & 3.86 & 0.97 & 4.01 & 3.80 & 3.67 & 0.99 & 4.64 & 1.02 & 4.70 & 4.20 \\
\hline Total & 100 & 99.99 & 100 & 100 & 99.99 & 100 & 100 & 100 & 100 & 99.99 & 100.01 & 100 \\
\hline \multicolumn{13}{|c|}{ apfu (3 oxygens) } \\
\hline $\mathrm{Si}$ & 1.00 & 1.00 & 1.01 & 1.00 & 1.00 & 1.01 & 1.01 & 1.01 & 1.01 & 1.00 & 1.01 & 1.01 \\
\hline $\mathrm{Mg}$ & 0.02 & 0.05 & 0.02 & 0.05 & 0.02 & 0.02 & 0.02 & 0.06 & 0.02 & 0.05 & 0.03 & 0.03 \\
\hline$M n$ & 0.88 & 0.93 & 0.88 & 0.93 & 0.88 & 0.88 & 0.87 & 0.90 & 0.85 & 0.93 & 0.84 & 0.85 \\
\hline $\mathrm{Ca}$ & 0.09 & 0.02 & 0.09 & 0.02 & 0.09 & 0.09 & 0.08 & 0.02 & 0.11 & 0.02 & 0.11 & 0.10 \\
\hline
\end{tabular}

${ }^{\text {aSample/crystal }}$

$\mathrm{Fe}_{2} \mathrm{O}_{3}$ was below detection limits $(0.1 \mathrm{wt} . \%)$. 


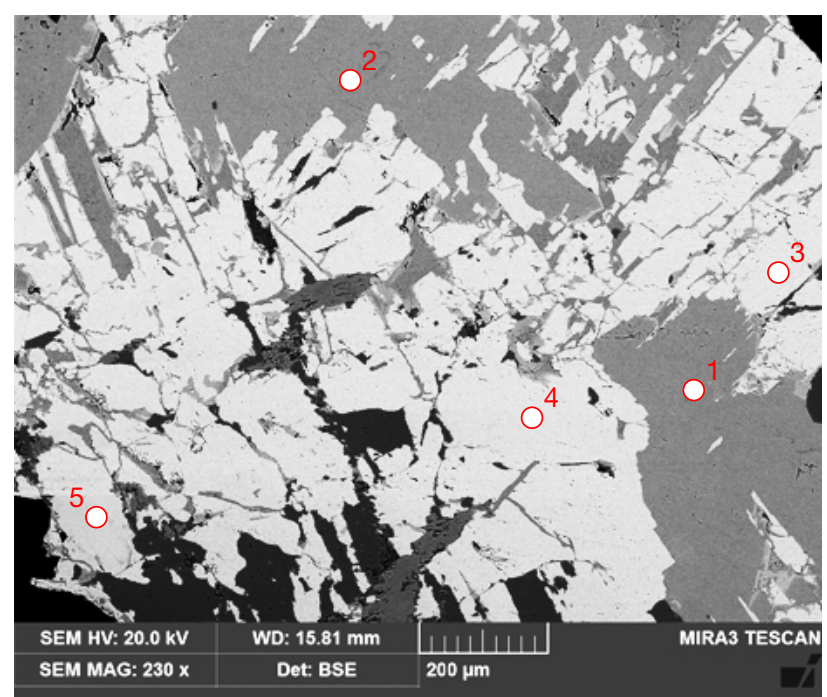

Figure 8. Backscattered electron image of rhodonitel pyroxmangite (points 3, 4, and 5) and associated kutnohorite (points 1 and 2) in rough sample 2.

rhodonites from the famous deposits of Broken Hill (Australia) and Franklin (New Jersey), Fe is an important chromophore element; again, see table 4.

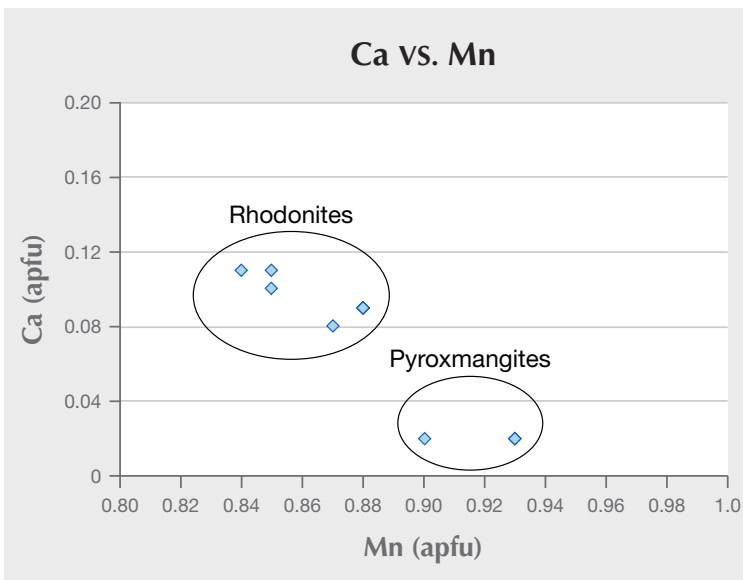

Figure 9. Compositional variation of Ca vs. Mn of coexisting rhodonite-pyroxmangite from Tanatz Alp in Switzerland.

Micro-Raman Spectroscopy. Mineral polymorphs are distinguishable by Raman spectroscopy (Mazzoleni et al., 2015), and this analysis was carried out to confirm the presence of the polymorph pyroxmangite with rhodonite.

TABLE 4. Chemical composition (wt.\%) of rhodonite samples reported in the literature: Italy (Peters et al., 1978; Mottana 1986; Diella et al., 2014); United States and Australia (Nelson and Griffin, 2005); and Japan (Aikawa, 1984).

\begin{tabular}{|c|c|c|c|c|c|c|c|c|c|c|c|c|c|c|}
\hline Oxides & $\begin{array}{c}\text { Italy } \\
\left(\text { Praborna }^{\mathrm{a}}\right)\end{array}$ & $\begin{array}{c}\text { Italy } \\
\text { (Val } \\
\text { Malenco 1) }\end{array}$ & $\begin{array}{c}\text { Italy } \\
\text { (Val } \\
\text { Malenco 2) }\end{array}$ & $\begin{array}{c}\text { Italy } \\
(\text { Val } \\
\left.\text { Sesia }^{a}\right)\end{array}$ & $\begin{array}{c}\text { Italy } \\
(\text { Monte } \\
\left.\text { Alpe }^{a}\right)\end{array}$ & $\begin{array}{c}\text { United } \\
\text { States } \\
\text { (Franklin } \\
\text { Mine 1, } \\
\text { New } \\
\text { Jersey) }\end{array}$ & $\begin{array}{c}\text { United } \\
\text { States } \\
\text { (Franklin } \\
\text { Mine 2, } \\
\text { New } \\
\text { Jersey) }\end{array}$ & $\begin{array}{l}\text { United } \\
\text { States } \\
\text { (New } \\
\text { York) }\end{array}$ & $\begin{array}{c}\text { United } \\
\text { States } \\
\text { (Plainfield, } \\
\text { Maine) }\end{array}$ & $\begin{array}{c}\text { Australia } \\
\text { (Broken } \\
\text { Hill) }\end{array}$ & $\begin{array}{c}\text { Australia } \\
\text { (Broken } \\
\text { Hill) }\end{array}$ & $\begin{array}{c}\text { Australia } \\
\text { (Broken } \\
\text { Hill) }\end{array}$ & $\begin{array}{c}\text { Japan } \\
\text { (Sankei) }\end{array}$ & $\begin{array}{c}\text { Japan } \\
\text { (Sankei) }\end{array}$ \\
\hline $\mathrm{SiO}_{2}$ & 46.82 & 46.76 & 46.40 & 46.91 & 46.70 & 46.35 & 46.46 & 45.71 & 45.69 & 46.15 & 45.94 & 45.83 & 46.88 & 47.34 \\
\hline $\mathrm{TiO}_{2}$ & n.d. & n.d. & 0.07 & n.d. & n.d. & 0.04 & n.d. & 0.01 & 0.01 & n.d. & 0.04 & 0.02 & n.d. & n.d. \\
\hline $\mathrm{Al}_{2} \mathrm{O}_{3}$ & n.d. & 0.02 & n.d. & n.d. & n.d. & 0.01 & 0.02 & 0.01 & 0.01 & 0.93 & 0.03 & 0.04 & 0.07 & 0.59 \\
\hline $\mathrm{MgO}$ & n.d. & 0.66 & 0.65 & 0.95 & 1.71 & 1.54 & 0.88 & 0.13 & 0.08 & 1.41 & 0.3 & 0.25 & 1.50 & 0.87 \\
\hline $\mathrm{FeO}$ & n.d. & 3.27 & 3.20 & n.d. & 5.21 & 2.79 & 1.91 & 12.34 & 1.93 & 10.51 & 11.76 & 11.92 & 0.45 & 0.31 \\
\hline $\mathrm{MnO}$ & 47.07 & 41.80 & 41.68 & 46.74 & 40.0 & 35.71 & 38.04 & 40.21 & 48.13 & 38.62 & 37.35 & 37.91 & 50.69 & 44.18 \\
\hline $\mathrm{ZnO}$ & n.d. & n.d. & n.d. & n.d. & n.d. & 6.96 & 5.09 & 0.16 & 0.03 & n.d. & 0.33 & 0.35 & n.d. & n.d. \\
\hline $\mathrm{CaO}$ & 6.11 & 6.41 & 6.79 & 5.40 & 6.38 & 6.59 & 7.61 & 1.73 & 3.65 & 2.01 & 4.32 & 3.94 & 1.37 & 7.11 \\
\hline Total & 100.00 & 100.02 & 99.99 & 100.00 & 100.00 & 99.99 & 100.01 & 100.30 & 99.53 & 99.63 & 100.07 & 100.26 & 100.06 & 100.41 \\
\hline \multicolumn{15}{|c|}{ Cations based on 3 oxygens apfu } \\
\hline $\mathrm{Si}$ & 1.00 & 1.006 & 1.000 & 1.00 & 0.99 & 0.994 & 0.996 & 0.994 & 0.994 & 0.992 & 0.993 & 0.991 & 0.998 & 0.998 \\
\hline $\mathrm{Ti}$ & n.d. & n.d. & 0.001 & n.d. & n.d. & 0.001 & n.d. & n.d. & n.d. & n.d. & n.d. & n.d. & n.d. & n.d. \\
\hline Al & n.d. & n.d. & n.d. & n.d. & n.d. & n.d. & 0.001 & n.d. & n.d. & 0.024 & 0.001 & 0.001 & 0.002 & 0.015 \\
\hline $\mathrm{Mg}$ & n.d. & 0.021 & 0.020 & 0.03 & 0.05 & 0.049 & 0.028 & 0.004 & 0.003 & 0.04 & 0.010 & 0.008 & 0.048 & 0.027 \\
\hline $\mathrm{Fe}$ & n.d. & 0.057 & 0.058 & n.d. & 0.09 & 0.050 & 0.034 & 0.224 & 0.035 & 0.188 & 0.213 & 0.216 & 0.008 & 0.031 \\
\hline$M n$ & 0.85 & 0.761 & 0.761 & 0.85 & 0.72 & 0.649 & 0.690 & 0.740 & 0.887 & 0.702 & 0.684 & 0.694 & 0.914 & 0.806 \\
\hline $\mathrm{Zn}$ & n.d. & n.d. & n.d. & n.d. & n.d. & n.d. & 0.081 & 0.003 & n.d. & n.d. & 0.005 & 0.006 & n.d. & n.d. \\
\hline $\mathrm{Ca}$ & 0.12 & 0.148 & 0.157 & 0.12 & 0.15 & 0.151 & 0.175 & 0.034 & 0.072 & 0.040 & 0.099 & 0.090 & 0.032 & 0.164 \\
\hline
\end{tabular}

aEDS analyses

n.d. $=$ not detected 
TABLE 5. EDS analyses of the five backscattered electron image spots from figure 8.

\begin{tabular}{|c|c|c|c|c|c|}
\hline $\begin{array}{l}\text { Oxides } \\
\text { (wt.\%) }\end{array}$ & $\begin{array}{c}1 \\
\text { (kutnohorite) }\end{array}$ & $\begin{array}{c}2 \\
\text { (kutnohorite) }\end{array}$ & $\begin{array}{c}3 \\
\text { (rhodonite/ } \\
\text { pyroxmangite) }\end{array}$ & $\begin{array}{c}4 \\
\text { (rhodonite/ } \\
\text { pyroxmangite) }\end{array}$ & $\begin{array}{c}5 \\
\text { (rhodonite/ } \\
\text { pyroxmangite) }\end{array}$ \\
\hline $\mathrm{MgO}$ & 1.79 & 1.81 & 1.37 & 1.28 & 1.53 \\
\hline $\mathrm{SiO}_{2}$ & - & - & 47.87 & 47.83 & 47.92 \\
\hline $\mathrm{CaO}$ & 26.03 & 25.31 & 3.79 & 3.89 & 4.58 \\
\hline $\mathrm{MnO}$ & 30.73 & 31.50 & 46.97 & 47.01 & 45.97 \\
\hline $\mathrm{CO}_{2 \text { calc }}$ & 41.45 & 41.38 & - & - & - \\
\hline \multirow[t]{2}{*}{ Total } & 100 & 100 & 99.99 & 100.01 & 100 \\
\hline & \multicolumn{2}{|c|}{ apfu (6 oxygens) } & \multicolumn{3}{|c|}{ apfu (3 oxygens) } \\
\hline $\mathrm{Mg}$ & 0.09 & 0.10 & 0.04 & 0.04 & 0.05 \\
\hline $\mathrm{Si}$ & - & - & 1.01 & 1.01 & 1.01 \\
\hline $\mathrm{Ca}$ & 0.99 & 0.96 & 0.09 & 0.09 & 0.10 \\
\hline Mn & 0.92 & 0.94 & 0.85 & 0.86 & 0.82 \\
\hline $\mathrm{C}$ & 2 & 2 & - & - & - \\
\hline
\end{tabular}

The Raman spectrum of the sample shown in figure $6 \mathrm{~A}(\mathrm{area})$ is presented in figure 10 . The spectrum is characterized by an intense band at $1000 \mathrm{~cm}^{-1}$ assigned to the 1 symmetric stretching mode and two bands at 972 and $944 \mathrm{~cm}^{-1}$ assigned to the $v_{3}$ asymmetric stretching modes. The band at $670 \mathrm{~cm}^{-1}$ has been assigned to the $v_{4}$ Si-O-Si bending mode (Mills et al., 2005). The low wavenumber region of rhodonite is complex (Mills et al., 2005). There are two small bands at 399 and $424 \mathrm{~cm}^{-1}$ assigned to the $v_{2}$ bending mode. The spectra reported in literature are very similar to ours; the small differences observed can be attributed to cationic substitution of $\mathrm{Mn}$ by $\mathrm{Ca}, \mathrm{Fe}$, and $\mathrm{Mg}$ (Mills et al., 2005; Diella et al., 2014).
The Raman spectra of pyroxmangite (from the RRUFF database, ID R070212 at rruff.info) present many bands that overlap with those of rhodonite (figure 10). However, the small bands at 185, 252, and $299 \mathrm{~cm}^{-1}$ are characteristic of pyroxmangite and confirm the presence of this polymorph in our samples.

\section{DISCUSSION AND CONCLUDING REMARKS}

The present study, performed on both cut and rough samples of rhodonite-rich rocks from Tanatz Alp, provided new data to better understand the characteristics of this attractive gemstone.

The color of the investigated rhodonite rocks varied from pale pink to purplish pink. The mineralogi-

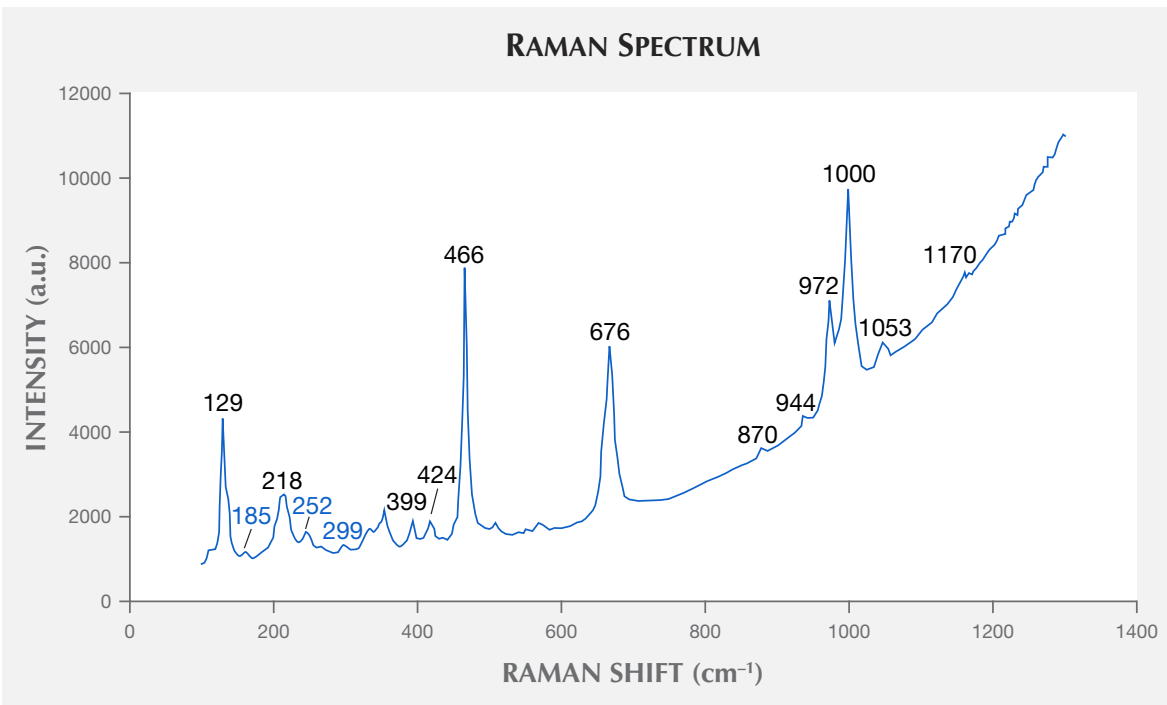

Figure 10. Raman spectrum of the rhodonite from figure $6 \mathrm{~A}$ (area $\mathrm{b}$ ). 
cal composition is an assemblage of rhodonite and pyroxmangite and other Mn-rich minerals such as kutnohorite, spessartine, ankerite, and rhodochrosite. Low amounts of chlorite, calcite, and quartz were also detected. We also identified the presence, as an accessory phase, of khristovite, a Ce-Fe- $\mathrm{Mn}^{2+}$-rich epidote group mineral. This finding is very interesting owing to the rarity of this mineral; the presence of khristovite in this locality was also reported by Roth and Meisser (2011).

The chemical composition of our rhodonite samples highlights a negative correlation between $\mathrm{Ca}$ and $\mathrm{Mn}$, which was previously observed in rhodonites from Tanatz Alp and the Rhetic Alps (Peters et al., 1978; Diella et al., 2014). The amount of Mg ions substituting for $\mathrm{Mn}$ in the samples we analyzed showed large variations that reflect the type of carbonate mineral present, the bulk composition of the mother rock and the availability of the element (Diella et al., 2014). It is interesting to observe that our samples did not show the presence of $\mathrm{FeO}$, which has been reported in rhodonites from other occurrences such as Broken
Hill (up to about 12\%; Millsteed et al., 2005; Millsteed, 2006), Franklin (up to about 2.8\%; Nelson and Griffen, 2005), and Val Malenco (up to 3.27\%; Diella et al., 2014). Together with $\mathrm{Mn}$ and $\mathrm{Ca}$, Fe substitutes for $\mathrm{Mg}$ in the octahedral sites of the mineral's structure. The presence of Fe modifies the color from pink to deep pinkish red, as reported for rhodonites from Broken Hill and the Franklin mine, which are Fe-rich and have a deep pinkish red color (Millsteed, 2005; Nelson and Griffen, 2005). Since Fe is absent in our samples, the color is softer; the Praborna material, which also lacks $\mathrm{Fe}$, is similar in color to our samples from Tanatz Alp.

The Ca content in our rhodonites ranged between $0.97 \%$ and $4.70 \mathrm{wt} . \%$, lower than that of other rhodonites from the Alps (table 4). The variability of $\mathrm{Ca}$ content in deposits worldwide can be related to the coexistence of pyroxmangite and rhodonite.

XRPD patterns, micro-Raman analyses, and low Ca contents indicate that the pyroxmangite should coexist with rhodonite in the Mn-rich rocks from
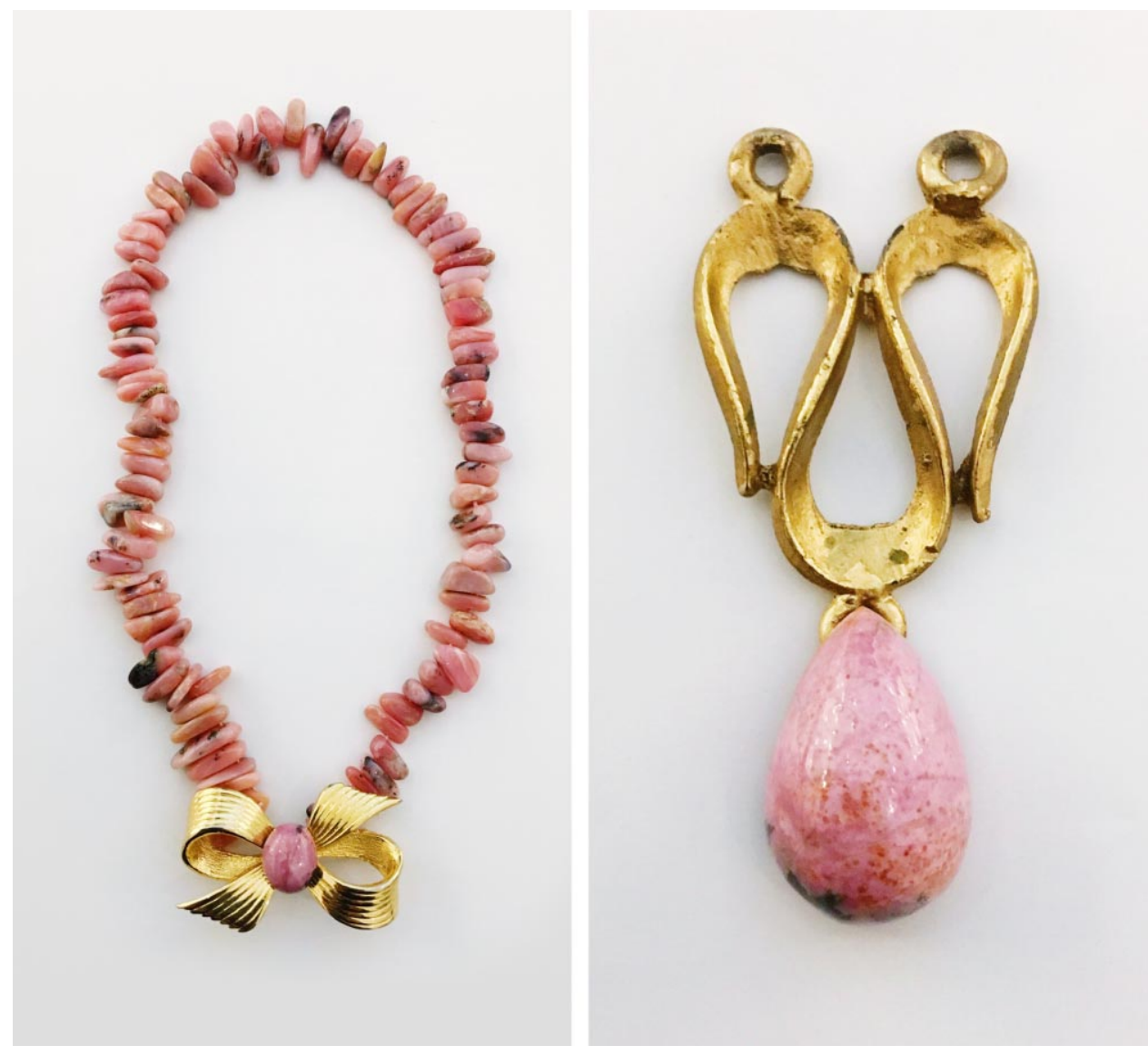

Figure 11. Handmade jewels produced with rhodonite from Tanatz Alp by Lutezia Gioielli (Stradella, Italy). Left: necklace of freeform rhodonite beads. The knot in the center of the necklace contains a pink rhodonite cabochon. Right: Vintage pendant with a dropshaped rhodonite. Photos by Federica Montanelli. 
Tanatz Alp. The pyroxmangite crystals probably intergrow with rhodonite crystals, but the two phases are visually undetectable. The intergrowth of the two phases is also confirmed by the large variability of $\mathrm{Ca}$ in the same areas of EDS analyses, ranging from 0.02 to $0.10 \mathrm{apfu}$. Both polymorphs usually form through processes of regional or contact metamorphism, as well as metasomatic processes from carbonate rocks that underwent low-grade regional or very high-grade contact-metamorphic conditions (Abrecht, 1988). Several studies on the coexistence of pyroxmangite and rhodonite have been performed on synthetic crystals of $\mathrm{MnSiO}_{3}$; synthetic pyroxmangite is usually stable at temperatures below about $400^{\circ} \mathrm{C}$ and pressures $<2$ kbar, while rhodonite is stable at higher temperatures (Abrecht and Peters, 1975; Maresch and Mottana, 1976; Pinckney and Burnham,1988).Yet the application of these studies to natural rocks is quite difficult because of the great variety and the extent of cation substitutions observed in natural pyroxenoids (Ca, $\mathrm{Mg}, \mathrm{Fe}^{2+} \rightarrow \mathrm{Mn}$ ).

Furthermore, the inability to identify the original outcropping represents a significant challenge in un- derstanding the genesis of the manganese mineralization of Tanatz Alp.

Regarding gemological properties, the rhodonitebearing rocks investigated in this study were compact with no fractures. They also showed a pink color, though it was not homogeneous and contained orange and purple tints due to spessartine and rhodochrosite, respectively. Since these rhodonites are translucent and microcrystalline, their commercial value is far lower than that of the transparent gems from Broken Hill (Millsteed, 2005) or Franklin (Nelson and Griffen, 2005). Although some Tanatz Alp rhodonites were carved and traded in the past, their marketing did not begin until the end of the twentieth century. This charming pink stone with a fine-grained structure is now available for pendants, necklaces, brooches, and ornamental objects (figure 11).

At present the deposit is only mined occasionally with hand tools and not for commercial purposes. Despite the difficulty of access, the geological characteristics of the locality suggest the possibility of substantial future production if a small commercial mine were to be established.
ABOUT THE AUTHORS

Dr. Caucia is associate professor, Dr. Marinoni is a geologist, and Dr. Riccardi is associate professor with the Department of Earth Sciences and Environment, University of Pavia, Italy. Dr. Bartoli is associate professor with the Department of Geosciences, University of Padova, Italy. Dr. Scacchetti is a geologist with Reggiana Society of Natural Sciences, Reggio Emilia, Italy.

\section{ACKNOWLEDGMENTS}

The authors are grateful to Antonio Langone for help during the traces analyses, Mattia Gilio for micro-Raman analyses,

Francesco Vanini for supplying the rhodonite samples, Federica Montanelli for the gem photography, and Riccardo Fantini and Francesco Leoni for the creating the illustrations.

\section{REFERENCES}

Abrecht J. (1988) Experimental evaluation of the $\mathrm{MnCO}_{3}$ $+\mathrm{SiO}_{2}=\mathrm{MnSiO}_{3}+\mathrm{CO}_{2}$ equilibrium at $1 \mathrm{kbar}$. American Miner alogist, Vol. 73, No. 11-12, pp. 1285-1291.

Abrecht J., Peters T. (1975) Hydrothermal synthesis of pyroxenoid in the system $\mathrm{MnSiO}_{3}-\mathrm{CaSiO}_{3}$ at $\mathrm{Pf}=2 \mathrm{~kb}$. Contributions to Mineralogy and Petrology, Vol. 50, No. 4, pp. 241-246, http://dx.doi.org/10.1007/BF00394851

Aikawa N. (1984) Lamellar structure of rhodonite and pyroxmangite intergrowths. American Mineralogist, Vol. 69, No. 3-4, pp. 270-276.

Akaogy M., Navrotsky A. (1985) Calorimetric study of high-pressure polymorph of $\mathrm{MnSiO}_{3}$. Physics and Chemistry of Minerals, Vol. 12, No. 6, pp. 317-323, http://dx.doi.org/10.1007/BF00654341

Armbruster T., Bonazzi P., Akasaka M., Bermanec V., Chopin C., Gieré R., Heuss-Assbichler S., Liebscher A., Menchetti S., Pan Y., Pasero M. (2006) Recommended nomenclature of epidotegroup minerals. European Journal of Mineralogy, Vol. 18, No. 5, pp. 551-567, http://dx.doi.org/10.1127/0935-1221/2006/ 0018-0551

Bedogné F., Montrasio A., Sciesa E. (1993) I minerali della Provincia di Sondrio. Bettini Editore, Sondrio.
Bedogné F., Maurizio R., Montrasio A., Sciesa E. (1995) I minerali della Provincia di Sondrio e della Bregaglia Grigionese. Val Bregaglia, Val Masino, Val Codera, Bettini Editore, Sondrio.

Bertolani M. (1967) Rocce manganesifere tra le granuliti della Valle Strona (Novara). Periodico di Mineralogia, Vol. 36, pp. 10111032.

Biggioggero B., Montrasio A. (1990) Val Chiavenna e Valle Spluga. Itinerario n. 9. In Guide Geologiche Regionali. 1. Alpi e Prealpi Lombarde. Società Geologica Italiana, BE-MA Editore Milano.

Brown P.E., Essene E.J., Peacor D.R. (1980) Phase relations inferred from field data for $\mathrm{Mn}$ pyroxenes and pyroxenoids. Contributions to Mineralogy and Petrology, Vol. 74, No. 4, pp. 417-425, http://dx.doi.org/10.1007/BF00518121

Brugger J., Giere R. (1999) As, Sb and Ce enrichment in minerals from a metamorphic Fe-Mn deposit, Val Ferrera, Eastern Swiss Alps. Canadian Mineralogist, Vol. 37, pp. 37-52.

Brusnitsyn A.I. (2010) Mineralogy of metamorphosed manganese deposits of the South Urals. Geology of Ore Deposits, Vol. 52, No. 7, pp. 551-565, http://dx.doi.org/10.1134/S1075701510070044

Bukanov V.V. (2006) Russian Gemstones Encyclopedia. Granit Editor, Saint Petersburg. 
Capitani G.C., Grobéty H.B., Mellini M. (2003) Reaction sequences, polysomatic faults and chemical compositions of manganese pyroxenoids from Campiglia Marittima skarn. European Journal of Mineralogy, Vol. 15, No. 2, pp. 381-391, http://dx.doi.org/10.1127/0935-1221/2003/0015-0381

Deer W.A., Howie R.A., Zussman J. (1997) Rock Forming Minerals, Vol. 2A, 2nd ed. Single Chain Silicates. The Geological Society, London.

Degen T., Sadki M., Bron E., König U., Nénert G. (2014) The HighScore suite. Powder Diffraction, Vol. 29, No. S2, pp. S13-S18, http://dx.doi.org/10.1017/S0885715614000840

Di Sabatino B. (1967) Su una paragenesi del giacimento manganesifero di Scortico (Alpi Apuane). Periodico di Mineralogia, Vol. 36, pp. 965-992.

Diella V., Adamo I., Bocchio R. (2014) Gem-quality rhodonite from Val Malenco (Central Alps, Italy). Periodico di Mineralogia, Vol. 83, pp. 207-221.

Grenouillet W. (1920) Geologische Untersuchungen am Splügenpass und Mte di San Bernardino. Jahresbericht der Naturforschenden Gesellschaft Graubundens, N.F. 60, pp. 31-60.

Ito J. (1972) Rhodonite-pyroxmangite peritectic along the join $\mathrm{MnSiO}_{3}-\mathrm{MgSiO}_{3}$ in air. American Mineralogist, Vol. 5, pp. 865876.

Jefferson D.A., Pugh N.J., Alario-Franco M., Mallison L.G., Millward G.R., Thomas J.M. (1980) The ultrastructure of pyroxenoid chain silicates. I. Variation of the chain configuration in rhodonite. Acta Crystallographica Section A, Vol. 36, No. 6 pp. 1058-1065, http://dx.doi.org/10.1107/S0567739480002136

Kenngott A. (1866) Die Minerale der Schweiz. Engelmann Editor, Leipzig.

Lee D.E. (1958) An andradite-spessartine garnet from Pajsberg, Sweden. American Mineralogist, Vol. 43, pp. 208-215.

Leverett P., Williams P.A., Hibbs D.E. (2008) Ca-Mg-Fe-rich rhodonite from the Morro da Mina mine, Comselheiro Lafaiete, Minas Gerais, Brazil. Mineralogical Record, Vol. 39, No. 2, pp. 125-130.

Mancini S. (1997) Le miniere di manganese di Scortico (Fivizzano, Massa-Carrara). Rivista Mineralogica Italiana, Vol. 3, pp. 295296.

Marchesini M., Pagano R. (2001) The Val Graveglia manganese district, Liguria, Italy. Mineralogical Record, Vol. 32, No. 5, pp. 349-379.

Maresch W.V., Mottana A. (1976) The pyroxmangite-rhodonite transformation for the $\mathrm{MnSiO}_{3}$ composition. Contributions to Mineralogy and Petrology, Vol. 55, No. 1, pp. 69-79, http://dx.doi.org/10.1007/BF00372755

Markvardsen A.J., Shankland K., David W.I.F., Johnston J.C., Ibberson R.M., Tucker M., Nowell H., Griffin T. (2008) ExtSym: a program to aid space-group determination from powder diffraction data. Journal of Applied Crystallography, Vol. 41, No. 6, pp. 1177-1181, http://dx.doi.org/10.1107/S0021889808031087

Mazzoleni P., Barone G., Aquilia E., Bersani D., Cirrincione R., Raneri S. (2015) Application of micro-Raman spectroscopy for the identification of unclassified minerals preserved in old museum collections. Plinius, Vol. 42, pp. 112-120, http://dx.doi.org/ 10.19276/plinius.2016.02015

Michailidis K., Sofianska E. (2010) Spheroidal and radiating aggregates of Mn-pyroxenoids in the Olympias carbonate-hosted polymetallic sulphide ore deposit, E. Chalkidiki peninsula, N. Greece. Review of the Bulgarian Geological Society, Vol. 71, pp. 59-68.

Mills S.J., Frost R.L., Kloprogge J.T., Weier M.L. (2005) Raman spectroscopy of the mineral rhodonite. Spectrochimica Acta,
Vol. 62, No. 1-3, pp. 171-175, http://dx.doi.org/10.1016/ j.saa.2004.12.022

Millsteed P.W. (2006) Faceting transparent rhodonite from Broken Hill, New South Wales, Australia. Ge)G, Vol. 42, No. 2, pp. 151-158, http://dx.doi.org/10.5741/GEMS.42.2.151

Millsteed P.W., Mernagh T.P., Otieno-Alego V., Creagh D.C. (2005) Inclusions in transparent gem rhodonite from Broken Hill, New South Wales, Australia. GÆG, Vol. 41, No. 3, pp. 246254, http://dx.doi.org/10.5741/GEMS.41.3.246

Mottana A. (1986) Blueschist-facies metamorphism of manganiferous cherts: A review of the alpine occurrences. In B.W. Evans and E.H. Brown, Eds., GSA Memoirs: Blueschists and Eclogites, Vol. 164, pp. 267-300, http://dx.doi.org/10.1130/MEM164-p267

Nelson W.R., Griffen D.T. (2005) Crystal chemistry of Zn-rich rhodonite ("fowlerite"). American Mineralogist, Vol. 90, No. 5-6, pp. 969-983, http://dx.doi.org/10.2138/am.2005.1694

Ohashi Y., Kato A., Matsubara S. (1975) Pyroxenoids: A variation in chemistry of natural rhodonite and pyroxmangite. In Carnegie Institution of Washington Year Book 75.

Peters T., Schwander H., Trommsdorff V. (1973) Assemblages among tephroite, pyroxmangite, rhodochrosite, quartz: Experimental data and occurrences in the Rhetic Alps. Contributions to Mineralogy and Petrology, Vol. 42, No. 4, pp. 325-332, http://dx.doi.org/10.1007/BF00372610

Peters T., Trommsdorff V., Sommerauer J. (1978) Manganese pyroxenoids and carbonates: Critical phase relations in metamorphic assemblages from the Alps. Contributions to Mineralogy and Petrology, Vol. 66, No. 4, pp. 383-388, http://dx.doi.org/ 10.1007/BF00403423

Pinckney L.R., Burnham C.W. (1988) Effects of compositional variation on the crystal structures of pyroxmangite and rhodonite. American Mineralogist, Vol. 73, No. 7-8, pp. 798-808.

Quinn E.P. (2004) Gem News International: Rhodonite of facet and cabochon quality from Brazil. $G \uplus G$, Vol. 40, No. 3, pp. 260261.

Roth P., Meisser N. (2011) I minerali dell'Alpe Tanatz. Passo dello Spluga (Grigioni, Svizzera). Rivista Mineralogica Italiana, Vol. 17 , pp. 90-99.

Schiavinato G. (1953) Sulla johannsenite dei giacimenti a silicati manganesiferi del Monte Civillina presso Recoaro (Vicenza). Rendiconti Società Mineralogica Italiana, Vol. 9, pp. 210-218.

Simandl G.J., Paradis S., Nelson J. (2001) Jade and rhodonite deposits, British Columbia, Canada. In L. Bon, Ed., Proceedings of the 35th Forum on the Geology of Industrial Minerals: The Intermountain West Forum, 1999. Utah Geological Survey, Salt Lake City.

Takahashi K., Hariya Y. (1995) Phase relations of pyroxenoid in the system $\mathrm{MnSiO}_{3}-\mathrm{MgSiO}_{3}-\mathrm{CaSiO}_{3}$. In J. Pašava et al., Eds. Mineral Deposits: From Their Origin to Their Environmental Impacts. CRC Press, Prague, pp. 1011-1014.

Trommsdorff V., Schwander H., Peters T. (1970) Mangasilikate der alpine metamorphose in Radiolariten des Julier-Bernina-Gabietes. Schweizerische Mineralische und Petrographische Mitteilungen, Vol. 50 pp. 539-545.

Wenk H.R., Maurizio R. (1978) Kutnahorite, a rare Mn mineral from Piz Cam (Bergell Alps). Schweizerische Mineralische und Petrographische Mitteilungen, Vol. 58, pp. 97-100.

Wilson W.E. (1989) What's new in minerals: Springfield Show 1989. Mineralogical Record, Vol. 20, No. 1, p. 481.

Zanazzi P.F., Nestola F., Nazzareni S., Comodi P. (2008) Pyroxmangite: A high-pressure single crystal study. American Mineralogist, Vol. 93, No. 11-12, pp. 1921-1928, http://dx.doi.org/ 10.2138/am.2008.2963 